This item was submitted to Loughborough's Research Repository by the author.

Items in Figshare are protected by copyright, with all rights reserved, unless otherwise indicated.

\title{
Sport, policy and politics in Lebanon
}

PLEASE CITE THE PUBLISHED VERSION

http://dx.doi.org/10.1080/19406940.2014.914553

\section{PUBLISHER}

(c) Taylor \& Francis

\section{VERSION}

AM (Accepted Manuscript)

\section{PUBLISHER STATEMENT}

This work is made available according to the conditions of the Creative Commons Attribution-NonCommercialNoDerivatives 4.0 International (CC BY-NC-ND 4.0) licence. Full details of this licence are available at: https://creativecommons.org/licenses/by-nc-nd/4.0/

\section{LICENCE}

CC BY-NC-ND 4.0

\section{REPOSITORY RECORD}

Nassif, Nadim, and Mahfoud Amara. 2019. "Sport, Policy and Politics in Lebanon". figshare. https://hdl.handle.net/2134/17948. 
To cite this article: Nadim Nassif \& Mahfoud Amara (2015): Sport, policy and politics in Lebanon,International Journal of Sport Policy and Politics, DOI: 10.1080/19406940.2014.914553

Nadim Nassifa \& Mahfoud Amarab a Department of Psychology, Education and Physical Education, Notre Dame University, Zouk Mosbeh, Lebanon

b School of Sport, Exercise and Health Sciences, Loughborough University, Ashby Road, LE11 3TU, Loughborough, UK Published online: 26 J an 2015.

Lebanon offers an interesting context for the study of sport policy as there is a lack of literature on sport policies in developing countries, and particularly, in small- and multi-confessional societies. Hence, the aim of this study was to illustrate how the dynamic of power between the state and the political parties/ confessional communities is reflected in the national sport system. In particular the paper seeks to provide some insight into the mechanism in place to implement the concept of 'balance of power' or so-called mosaic society within the national sport system, looking specifically at structure and resource allocation.

Keywords: Lebanon; sport policy; confessionalism; political parties; national sport system 


\section{Introduction}

The successive foreign powers that occupied the country and the multitude of different religious communities that have coexisted inside Lebanon (Salibi 1993) have not only contributed to the emergence of a modern nation that enjoys very rich cultural and religious diversities, but also founded a republic governed by a fragile balance of power. It was under the umbrella of this inherent legacy of internal tensions, and the almost 'natural' dependency of the Lebanese Government on foreign powers, that the independence of Lebanon was declared in 1943 (Salibi 1965, 1993).

To establish a republic where the main characteristic would be a fair division of powers between the various communities, it was therefore officially decided henceforth that the President of the Republic would be a Christian Maronite, the Prime Minister, a Muslim Sunnite and the Assembly President, a Muslim Shiite. The other smaller communities (Druzes, Christian Orthodox, Christian Catholics, Armenians, etc.) would also have a quota in the government (Bustros 1973). At that time Lebanese politicians thought that this compromise was essential to secure political stability. This explains why Lebanon is a unique country, and it is next to impossible to find, in the whole world, a small place of 10,452 square kilometres, and a population of less than 10 million, embracing 18 different religious communities. However, despite these measures aimed at establishing a balance of power, tension remained between different communities and it had often led to major conflicts, which in turn resulted in an ongoing unsteady political and economic situation.

The tension and competition between different religious communities are also apparent in the sporting domain. Indeed, although there is no official distribution of powers according to religious affiliations inside the national sport system, compromises are,

however, informally in place to promote an internal 'peaceful climate' within various sport institutions. These informal arrangements and tacit agreement between different protagonists, allow every community to have influence in the national sport system, although very often this led to situations of mismanagement and division, which in turn have strongly affected the implementation of sport policies in the country.

In terms of structure, we start by providing an account of the political system. In the second part we identify the key features of the national sport system. The final part is devoted to the analysis of political interference in sport particularly in relation to structure and resource allocation.

\section{The Lebanese political system}

The multi-confessional political system is the principal trait of Lebanese society. There are 18 different communities in Lebanon that can be clustered under three main groups:

(1) Muslims which constitute $59.7 \%$ of the population (Shi'a, Sunni, Druze, Ismaeli, Alaoui); 
(2) Christians which represent 39\% of the population (Maronites, Orthodox, Melkites, Catholics, Armenian orthodox, Syrian Catholics, Armenian Catholics, Syrian Orthodox, Roman Catholics, Chaldeans, Assyrians, Copts and Protestants); and

(3) other small minorities representing 1.3\% of the population.

With this large palette of religious groups on such a small geographical surface, and taking into account the legacy of the civil war from 1975 till 1989, establishing a government that is able to establish and maintain 'harmony' between different commu- nities has become a major issue. In fact, the authors of the constitution, although aware of how difficult it is, have always had the spirit and the will to establish a non-confessional state. Therefore, it was agreed that a secular state (laïque according French tradition) separating between religion and political affairs should be gradually established as stated in the 1926 constitution, the 1943 national pact and the Taef agreement signed on 22

October 1989 by different protagonists of the civil war and ratified later on by the Lebanese Parliament.

However, the constitution failed to resolve certain ambiguities that have made the principle of 'just equilibrium' between communities hard to accomplish. Indeed, even though the preamble (9th, 10th and 19th paragraphs) clearly indicates that religious beliefs and diversities should not, under any circumstances, interfere with the path that the government is taking; articles 22, 24 and 95 indicate also that equal participation of religious groups in the heart of the state is mandatory to eradicate confessionalism. These measures have many times proven to be contradictory, making it hard thus to consolidate consensus and national unity.

After the dismantlement of different militias by the Syrian army in 1990, most armed factions reclaimed themselves as political parties thus turning the Lebanese political system to a mixture of consociationalism and confessionalism (Reiche 2011). This designation was first used to explain how different religious groups in the Netherlands were able, at the beginning of the twentieth century, to overcome their rooted political differences in order to ally themselves and rule together. Consociationalism has, later on, spread and included other political systems like those of Belgium, Canada, Colombia, Lebanon and India.

On the other hand confessionalism is a system of rule where the authority is distributed among different communities, whether ethnic or religious, according to their size. It is used today to describe mainly the unique case of the Lebanese political system.

The 18 religious communities recognized by the constitution have two main functions:

(1) Responsibility over all legal matters related to personal status (like marriage, divorce, children custody and heritage). 
(2) Access to political positions attributed to them on a proportional basis, as dis- cussed earlier.

The Taef accord came as a reiteration of the 1943 National Pact and introduced changes to (questionably) the benefit of the increasing Muslim population. Muslims and Christians have the same number of seats in the Parliament whereas the National Pact attributed a 6/5 ratio to the Christians. Moreover, the powers of the President were narrowed while giving more powers to the Prime Minister in co-signing the decrees.

Similarly, the Doha accord signed on 23 May 2008 had put an end to the political vacuum which lasted for a year and a half, confirming thus the principle of the Taef agreement but also led to the formation of a government of national unity formed by ministerial positions distributed as follows: 16 from the majority, 11 from the opposition and 3 named by the President. The Doha agreement also stipulated that the various parties forming the government should guarantee not to resign or obstruct any actions undertaken by the government.

One can argue however that both the Doha and the Taef agreements reinforced the communities' roles as 'states within the state'. The influence of religious communities is to be found today in various sectors in Lebanese society. We can cite, for instance, the media sector, where each community has its own TV and Radio channels:

(1) 'Future TV', supporting the ideology of the Future party, was founded and financed by the former Prime Minister Rafik El-Hariri.

(2) 'Al Manar' channel supported by Hezbollah.

(3) 'NBN TV' supported by Amal party.

(4) 'OTV' takes the side of the Free Patriotic Movement.

Based on the above discussion the questions to be asked are as follows: how does sport mirror the political and communitarian oppositions within Lebanese society? Does sport prolong this ultra-confessional tendency? Can the latter be found in sport institutions and does it affect the sport policy process? To answer these questions two aspects are considered in the subsequent section:

(1) Roles and objectives of various actors in the national sport system

(a) What roles do they have?

(b) What relations do they maintain?

(2) The funding of the Lebanese sport

system (a) Where does the money come

from? (b) How is it allocated?

To answer these questions, in addition to document analysis, including Parliamentary debates, laws, government reports and newspaper articles, interviews were undertaken by the first author of this paper with personalities from the government, the Parliament and the national sport movement. 


\section{National sport system in Lebanon}

Having introduced the political system in Lebanon in the first part of this paper, this section focuses on the national sport system, including the policy measures around the organization of sport and roles of various actors. During the first part of the post-war period, that lasted almost a decade (1991-1999), the Lebanese government took no official measure in favour of sport. The advisor to the Ministry of Youth and Sports in the late 1990s, the former Lebanese champion in boxing and member of the Lebanese basketball team, Joseph Sacre, proposed a plan to reform the Lebanese sport system. The structure suggested by Sacre (1990) includes the following departments: the General Directorate of Youth and Sports (under the authority of the Ministry of Education); Lebanese National Olympic Committee, National Sport Federations; University Sport; School Sport; and Sport Associations.

Worth noting, this proposed structure was never established. ${ }^{1}$ Actually, no law related to the function of the Lebanese sport system was passed between 1991 and 1999. The period was marked, instead, by the establishment of a series of independent, separate and non-coordinated measures.

In 1993, the higher education sector granted universities the first permits to begin establishing physical education and sport programmes. ${ }^{2}$ Later on in 1997, according to decree 10227, physical education and sports was registered as an official school subject in the Lebanese school curriculum. ${ }^{3}$ The first drafted law aiming at defining national sport organization was submitted under the decree 247 signed in $2000,{ }^{4}$ which transformed the General Directorate of Youth and Sports into the Ministry of Youth and Sports (MYS). A Sport and Scouting unit was created inside the Ministry of Education in order to develop school sports. The monitoring of the National Olympic Committee (NOC), National Federations and Sports Associations has henceforth become the privilege of the newly established Ministry, whose budget was voted upon and whose actions were supervised by the Youth and Sports Committee in the Lebanese Parliament. The latter was formed at the same time as the Ministry of Youth and Sports, in 2000.

In December 2001, the decree 6997 was ratified by the Lebanese government, ${ }^{5}$ which defines the rules of every sport institutions whether the NOC, Sports Federations and Sports Associations, including the relation of these structures with the Ministry of Youth and Sports. With this decree the political institutions no longer have direct authority over the LOC (Lebanese Olympic Committee), which is directly accountable to the International Olympic Committee (IOC). Although, to preserve the national sovereignty, the MYS has the authority to recognize and dissolve national federations, whereas the LOC, despite its autonomy, has the authority to recognize sports that are part of regional Games such as the Pan Arab Games, the Mediterranean Games and the Islamic Solidarity Games, which are not necessarily organized under direct patronage of the IOC.

In 2004, the Youth and Sports Committee in the Parliament voted law 629 that elaborated the regulations governing the internal functioning of the MYS. ${ }^{6}$ In 2005, a collaboration programme between the French Embassy and the MYS was signed and two French sports experts, Henri-Pierre Gazzeri and Jean-François Isnard, were nominated in 2005 to study the possibility of creating a coaching diploma (inspired by the French coaching diploma) in Lebanon. On 27 March 2007, the last law to date concerning the 
Lebanese sport system was signed. The decree 213 came to replace the decree 6997 signed in $2001 .^{7}$ The main difference between the two is in relation to university sport.

\section{University sport}

The decree 213 placed the Lebanese Federation of University Sport (LFUS) under the authority of the Ministry of Education. The President of the LFUS, Nasri Lahoud, opposed the decision, on the basis that Article 14046, signed in 1946, stipulated that the LFUS was an independent federation recognized by the Lebanese government. According to George Nader, ${ }^{8}$ former basketball player, sports teams' director in Notre Dame University and General Secretary of the LFUS, the Ministry of Education wanted to set the foundations of a 'new' federation for university sports and thus to dismantle the LFUS. Furthermore, in Nader's terms, the Ministry of Education wanted to manipulate university sport without proposing any budget, and hence the decision was definitely based on political motives. It should be mentioned that the LFUS President is the sibling of the President of the Republic, Emile Lahoud (who was still the President in 2007, when the decree 213 was signed), the political rival of the Future party, which controls the Ministry of Education. Thus, the dispute over university sport constituted one of the arenas of conflict between, on the one hand, the Future party, founded by former Prime Minister Rafik El-Hariri who was assassinated on 14 February 2005, and President Emile Lahoud accused of being the 'henchman' of the Syrian regime, the prime suspect in the assassination of Hariri, on the other hand.

\section{School sport}

The other problem concerning the decree 213 is in relation to school sport. The MYS as well as the Youth and Sports Committee in the Parliament believe that school sport must be under the MYS, given that it could constitute a pool of talents for national sports federations. ${ }^{9}$ Unlike university sport, school sport used to be under the Sports and Scouting Unit (SSU) of the Ministry of Education and Higher Education since the decree 247 was signed in the year 2000. However, with the signature of the decree 213, the MYS and the Youth and Sports Committee in the Parliament hoped to change this by 'annexing' school sports to the MYS. In order to develop school sports, the Ministry of Education signed, on 26 January 2011, the decree 147/3/2011 aiming at 'transforming' the Sports and Scouting Unit of the Ministry of Education into a 'future' Lebanese Federation of School Sports, which is formed and financed by the school sports associations. Hence, schools willing to be part of this federation ought to form sports associations and pay annual enrolment fees. Using this money, the federation would be able to organize inter- schools league competitions. On the contrary, Adnan Hammoud, director of the SSU assumes, according to section 4 of Article 629 of the MYS, that all activities pertaining to school sports must be the privilege of the Ministry of Education. Therefore, this federation must also belong to the Ministry of Education. Politics comes again into play. In Hammoud's point of view, the 
problem is definitely political: 'the MYS is controlled by the Amal party, while the Ministry of Education belongs to the Future party, and both parties are rivals' ${ }^{10}$

The first conflict between the two structures took place in July 2010, when the Pan Arab School Games were held in Beirut. The MYS declared that it had to be in charge of the competition. According to Adnan Hammoud, the decree 147/3/2011 is 'the drop that flooded the vase'. He also declares that:

certain people want to put their hands on the Lebanese Federation of School Sports because they know that it will become the largest in Lebanon, in terms of the number of affiliated sports associations, and they can, thus, stuff their pockets with the great amounts of money that will flow from the participation fees in the federation (emphasis added).

\section{Sport and confessionalism}

The over-representation of religious communities in Lebanese sports at the expense of developing a transparent and functional structure is, according to Jihad Salame, ${ }^{11}$ candidate for the position of Minister of Youth and Sports for the 2013 legislative elections, strongly present in the national sport movement. All governmental institutions in the country follow, in reality, the same rule. Hence, many people are 'parachuted' into certain positions within certain federations because they represent or are supported by a political party. In conse- quence, $90 \%$ of people working at sports federations are not 'the right people at the right places', according to Salame, but rather the result of 'arrangements under the table' performed by various politicians. Several athletes openly declared recently in the media that the sport sector is the victim of 'bad management' and 'corruption'. ${ }^{12}$

This phenomenon of confessionalism in Lebanese sport was clearly highlighted in the studies of Blanc (2004), Boukhater (2004) and Reiche (2011) as well as Nseir's thesis (2012). Football and Basketball, the most popular sports, are cases in point. As illustrated in Tables 1 and 2 below, football and basketball clubs are strongly affiliated to political and religious parties divided into two main coalitions: the 14th of March and the 8th of March movements. The former whose principal leader is Saad El-Hariri, Sunni, son of the assassinated former Prime Minister Rafik El-Hariri, is a coalition between Future Movement, Sunni party, and the

Table 1. Sport, confessional belonging and political affiliation: example of first division football clubs for the season 2009-2010. 


\begin{tabular}{|c|c|c|}
\hline Club's name & Confessional belonging & Political affiliation \\
\hline ‘Al-Ahli' Sidon & Sunni Muslim Club & Future Party (March 14) \\
\hline $\begin{array}{l}\text { 'Al Ahed' } \\
\text { Beirut }\end{array}$ & Chiite Muslim Club & 'Hezbollah’ (March 8) \\
\hline $\begin{array}{l}\text { 'Al Ansar' } \\
\text { Beirut }\end{array}$ & Sunni Muslim Club & Future Party (March 14) \\
\hline $\begin{array}{l}\text { 'Al Islah Bourg } \\
\text { Shemaly' Tyr }\end{array}$ & Chiite Muslim Club & ‘Amal' Party (March 8) \\
\hline 'Sagesse' Beirut & Christian Maronite Club & Lebanese Forces (March 14) \\
\hline $\begin{array}{l}\text { 'Al Mabarra' } \\
\text { Beirut }\end{array}$ & Chiite Muslim Club & (March 8) \\
\hline $\begin{array}{l}\text { 'Shabab Al } \\
\text { Ghazieh' }\end{array}$ & Chiite Muslim Club & ‘Amal' Party (March 8) \\
\hline 'Nejmeh’ Beirut & $\begin{array}{l}\text { Club previously belonging to the Chiite } \\
\text { Muslim community, now belonging } \\
\text { to the Sunni Muslim community }\end{array}$ & Future Party (March 14) \\
\hline 'Racing' Beirut & Christian Orthodox Club & Future Party (March 14) \\
\hline $\begin{array}{l}\text { 'Safa Sporting } \\
\text { Club' Beirut }\end{array}$ & Druze Club & $\begin{array}{l}\text { Progressive Socialist Party (March } 14 \text { at } \\
\text { first, later moved to March } 8 \text { in } \\
\text { January 2011) }\end{array}$ \\
\hline $\begin{array}{l}\text { 'Shabab Al } \\
\text { Sahel' Beirut }\end{array}$ & Chiite Muslim Club & (March 8) \\
\hline 'Tadamon' Tyr & Chiite Muslim Club & (March 8) \\
\hline
\end{tabular}

Source: Reiche (2011, p. 264).

Table 2. Sport, confessional belonging and political affiliation: example of first division basketball clubs for the 2009-2010 season.

\begin{tabular}{lll}
\hline ‘Club name & Communal belonging & Political affiliation \\
\hline Anibal' Zahle & Christian Maronite Club & Free Patriotic Movement (March 8) \\
‘Antranik' Antelias & Christian Armenian Club & 'Ramgavar' (March 14) \\
‘Blue Stars' Beirut & Christian Maronite Club & Free Patriotic Movement (March 8) \\
‘Champville' Deek-El-Mehde de & Christian Maronite Club & Free Patriotic Movement (March 8) \\
‘Sagesse' Beirut & Christian Maronite Club & Lebanese Forces (March 14) \\
‘Hoops' Beirut & Chiite Muslim Club & (March 8) \\
‘Kahraba' Zouk & Christian Maronite Club & Lebanese Forces (March 14) \\
‘Al-Moutahed’ Tripoli & Sunni Muslim Club & Safadi Foundation (March 14) \\
‘Al-Riyadeh' Beirut & Sunni Muslim Club & Future Party (March 14) \\
'Sporting Club' Tebnine & Chiite Muslim Club & 'Amal' Party (March 8) \\
\hline
\end{tabular}

Source: Reiche (2011, p. 264).

Lebanese Forces and the Phalanges, which are Christian Maronites parties. They claim to be 'anti-Syrian', 'anti-Iranian', 'pro-Saudi' and 'pro-Western', whereas the latter is mainly composed of 'Hezbollah', 'Amal', Shi'a parties and the Free Patriotic Movement, Christian Maronite. They are accused of being ‘pro-Syrian’ and ‘pro-Iranian’ (Reiche 2011). 
In 2003, an interview with a coach of squash also revealed that some decisionmaking positions within certain federations are granted in order to preserve the 'equilibrium' among various communities (Nassif 2010). The coach suggested 'all federations are formed in conformity with this equilibrium. Some belong to Maronite Community while others belong to Sunni community or to Shi'a, etc...'. To illustrate this, Table 3 represents a list of Presidents and general secretaries of 32 Lebanese federations in 2003.

In 2003, among the 32 federations, only four combine Muslims and Christians. That is around $12.5 \%$ of the total number of federations. Similar phenomenon can be noticed for 2008 and 2009, as illustrated in Table 4.

Among the 32 federations listed, seven combine Muslims and Christians, a ratio of $21 \%$. Although the percentage of federations combining Muslims and Christians increased after 2003 (from 12.5\% to 21\%), around 80\% of federations are still managed by Presidents and general secretaries from the same community. Nseir (2012) looked at the religious belonging of all the members of Lebanese federations in 2009. Among the 34 federations included in the census, 16 (47\%) have a ratio exceeding $80 / 20 \%$ in favour of one of the communities, while 24 (70\%) have a ratio exceeding 70/30\% in favour of one community. Only one federation had a 50/50 ratio. Thus, it is evident that confessionalism is strongly spread in various sports institutions in the country. The fact that a sport is dominated by one religious community reduces significantly the number of people interested in it. Generally, athletes, referees and trainers are more prone to choose a sport which is managed by people of their own community. For instance in football, the second most practiced sport in Lebanon, among the 133 associations affiliated with the federation, $85 \%$ are composed by Muslim members (Nseir 2012). Furthermore, according to a research concerning table tennis, among the 22 associations affiliated with the federation during the 2009-2010 season, over 71\% were Christian (Nseir 2012).

In January 2013, it was announced in the media that the election for the Lebanese Olympic Committee will be taking into account the confessional belonging of each member. The lobbying of the political parties created a situation where the President of the Committee had to be Christian, the General Secretary Muslim Sunni and the treasurer Muslim Shi'a. ${ }^{13}$ It will be interesting to know what would be the reaction of the IOC 
Table 3. List of the federations along with the confessional belonging of their Presidents and general secretaries for the year 2003.

\begin{tabular}{|c|c|c|}
\hline National federation & $\begin{array}{c}\text { Confessional belonging of the } \\
\text { President }\end{array}$ & $\begin{array}{l}\text { Confessional belonging of } \\
\text { the general secretary }\end{array}$ \\
\hline Athletics & Christian & Christian \\
\hline Volleyball & Christian & Christian \\
\hline Tae Kwon do & Christian & Christian \\
\hline Rowing & Christian & Muslim \\
\hline Skiing & Christian & Christian \\
\hline Water Skiing & Christian & Christian \\
\hline Gymnastics & Christian & Christian \\
\hline Cycling & Christian & Christian \\
\hline Weight Lifting & Muslim & Muslim \\
\hline Shooting & Christian & Christian \\
\hline Badminton & Muslim & Muslim \\
\hline Swimming & Christian & Muslim \\
\hline Squash & Muslim & Muslim \\
\hline Fencing & Muslim & Christian \\
\hline Equestrian & Christian & Christian \\
\hline Kick-boxing & Muslim & Muslim \\
\hline Archery & Christian & Muslim \\
\hline Karate & Christian & Christian \\
\hline Basketball & Christian & Christian \\
\hline Tennis & Christian & Christian \\
\hline Handball & Muslim & Muslim \\
\hline Table Tennis & Christian & Christian \\
\hline Football & Muslim & Muslim \\
\hline Wrestling & Muslim & Muslim \\
\hline Boxing & Muslim & Muslim \\
\hline Wushu & Christian & Christian \\
\hline Sailing & Christian & Christian \\
\hline Chess & Muslim & Muslim \\
\hline Canoë-Kayak & Muslim & Muslim \\
\hline Muay Thai & Muslim & Christian \\
\hline Dance sport & Christian & Christian \\
\hline Paralympics & Muslim & Muslim \\
\hline
\end{tabular}

Source: The Lebanese Olympic Committee (table and information were provided by the assistant of the former president of the Lebanese Olympic Committee (approved by the president of the Lebanese Olympic Committee)).

towards this new plan with regard to questions of Olympic values, equality and the preservation of the NOCs from political intervention.

In the subsequent section we address the other important element, which informs the power relations and politico-religious dynamics within the national sport system, which is funding and resource allocation. 


\section{The funding system of Lebanese sport}

It is accepted that every budgeting cycle should normally include the following four main phases (Lee et al. 2008): preparation and submission; approval; implementation; and auditing and evaluation. Before the Ministry of Youth and Sports was established (following the decree 247) these phases were respected and applied in Lebanese national sport

Table 4. List of the federations along with the confessional belonging of their Presidents and general secretaries for the years 2008 and 2009.

\begin{tabular}{lll}
\hline $\begin{array}{l}\text { National } \\
\text { Federation }\end{array}$ & $\begin{array}{c}\text { Confessional belonging of the } \\
\text { President }\end{array}$ & $\begin{array}{l}\text { Confessional belonging of } \\
\text { the general secretary }\end{array}$ \\
\hline Taekwondo & Christian & Christian \\
Wushu & Christian & Christian \\
Canoë Kayak & Muslim & Muslim \\
Muay-Thai & Muslim & Muslim \\
Dance sport & Christian & Christian \\
Karate & Christian & Christian \\
Handball & Muslim & Christian \\
Volleyball & Christian & Christian \\
Basketball & Christian & Christian \\
Table Tennis & Christian & Christian \\
Kick-Boxing & Muslim & Muslim \\
Squash & Muslim & Christian \\
Gymnastics & Muslim & Christian \\
Shooting & Christian & Muslim \\
Football & Muslim & Muslim \\
Water Skiing & Christian & Christian \\
Badminton & Muslim & Christian \\
Archery & Christian & Muslim \\
Swimming & Christian & Christian \\
Weight Lifting & Muslim & Muslim \\
Boxing & Muslim & Muslim \\
Wrestling & Muslim & Muslim \\
Tennis & Christian & Christian \\
Skiing & Christian & Christian \\
Equestrian & Christian & Christian \\
Sailing & Christian & Christian \\
Cycling & Christian & Christian \\
Rowing & Muslim & Muslim \\
Fencing & Christian & Christian \\
Chess & Muslim & Christian \\
Athletics & Christian & Christian \\
Paralympics & Muslim & Muslim \\
\hline & & \\
& &
\end{tabular}

Source: The Lebanese Olympic Committee. 
system, but in non-continuous and unsystematic manners. By definition, continuous and systematic should mean a clarified budgeting that 'mechanically' repeats itself in a cyclical routine. In the United Kingdom, for instance, for every pound spent on the lottery, 33\% are allocated to a fund called the 'National Lottery Commission'. These funds cover the expenses for heritage, community, education and sport. This is how British sport organizations, for instance UK Sport, is financed. In turn, UK Sport distributes funds to sports federations according to their size (number of licensees) and international performance. In Lebanon, this financing method was never adopted prior to the year 2000. Government grants were mainly allocated to the organization of different sports events such as for the construction Sport City in 1957 to host the 1957 Pan Arab Games and the Mediterranean Games in 1959. Funds were also allocated to host the Pan Arab Games in 1997 and the Asian Cup in 2000 (Nassif 2010).

The year 2000 was a turning point for the financing system of Lebanese sport, with the signature of the decree 247 and the establishment of the Ministry of Youth and Sport. Consequently, a Parliamentary Committee of Youth and Sport, responsible, henceforth, for voting the budget allocated to the MYS, was created. The committee participates in the preparation and approval phases of the budget allocated to sport, in collaboration with the government. Once the approval is obtained, the government allocates the funds to the MYS in order to complete the implementation phase. Yet, one of the main gaps in the budgeting cycle has been the absence of auditing and evaluation, which led to malfeasances within various sports organizations. According to MYS officials, an annual report indicating which federations and sports associations deserve the financial aid, given their performance, is submitted to the MYS. ${ }^{14}$ However, when it comes to the implementation phase, it is common for the Ministry to receive 'phone calls' from high profile politicians requesting a share of the funding to their 'friendly' associations and federations. ${ }^{15}$

During a Parliamentary session in 2010, the President of the Youth and Sports Parliamentary Committee, Deputy Simon Abi Ramia, demanded every sport association and federation to submit a financial report for 2010. ${ }^{16}$ This constituted a historical event given that it was for the first time that an audit was seriously considered. According to Abi Ramia, the measure taken is essential to establish transparency within the Lebanese sport system, which is traditionally 'tainted' with corruption. In Abi Ramia's terms, the difficulties related to the implementation of this measure are the result of the 'politicisation' of different associations and federations 'belonging', in majority, to politico-religious communities. Although every religious community in the Parliament must have a quota according to its demographic weight, sport is in fact exempt from this law. However, 'on the field', sport remains informally structured according to political and religious allegiance. Sport Federations are under the 'protection' of political leaders and affiliated religious groups. The politicization of sport, a by-product of the confessional system, remains one of the main obstacles to good governance in sport in Lebanon.

In order to fight this 'anomaly' in the system, MYS along with the Youth and Sports Parliamentary Committee is currently studying a law that would 'force' the Minister to decide about the spending for only $20 \%$ of the budget. The other $80 \%$ would automatically be allocated to the Lebanese sport movement (Lebanese Olympic Committee, sport federations and associations) based on performance and number of participants and would 
therefore be protected from any political interference. ${ }^{17}$ According to Hassan Chararah, advisor to MYS, this would prevent political parties from influencing the Minister's decision to support sports federations and associations that are connected with his/her political party and religious community. The outcome of the law project is yet to be seen.

Similarly, in April 2011, Antoine Chartier (President of the LOC) requested the 32 federations, recognized by the LOC, to submit a financial report for the year 2010. ${ }^{18}$ This request, like the one by Deputy Abi Ramia, did not receive any response because of the 'political back up' that national sport federations can receive from political parties.

A funding system of the Lebanese national sport movement officially exists, but it is still dictated by political interference that stand in the face of adequate spending based on criteria of performance and efficiency. This funding system also suffers from the absence of a rigorous method of auditing and evaluation, which favours political interventions and 'arrangements'.

\section{Conclusion}

As illustrated in the paper the political system in Lebanon which is based on confessionalism is mirrored in the national sport movement and is impacting directly on its integrity. The interference of politics to serve the interests of different religious communities is impacting on mass sport participation as highlighted in the struggle between Ministry of Youth and Sports and Ministry of Education over the control of sport in schools and universities. The over-representation and dominance of one religious community over one sport is limiting the recruitment of participants and talents from other communities, as exemplified in football and basketball. The distribution of funding that favours sports associations and federations which are 'under political protection' and the absence of rigorous auditing and evaluation are tarnishing the image of the sport movement, and hence discouraging private investors, who are already traditionally 'shy' when it comes to sport, to invest in community and elite sports. In addition, sport is not attracting a significant fan base due to inter-religious violence, as clearly stated by Jean-Pierre Katrib, head of public relations for the Loubananouna, a federalist lobby group seeking a federalist solution to Lebanon's sectarian tensions:

Even our basketball teams are divided along the confessions. The Christian Blue Stars played the Sunni Riyadeh team the other day, and to rile each other up, Christian and Islamic religious slogans were being chanted on either side. (Abi-Habib 2007)

The inefficiency in the structure and the lack of public and private funding are constraining the development of sport in Lebanon and performance in international competitions. As clearly indicated by Stanton $(2012,2115)$ 'since 1947, Lebanon has fielded a team for every Olympic competition except 1956, yet has won only four Olympic medals: two silvers and two bronzes, for men's wrestling and weightlifting'. Since 1991, only eight athletes were able to qualify for the Olympic Games, with no one winning a medal. Slovenia, independent since 1992, with half population than Lebanon, won 22 medals. The only sport that achieved an international success is basketball. The national team qualified three times to the World Championship (2002, 2006 and 2010). This is mainly due to the contribution of players from Lebanese diaspora in Europe and 
North America, and a strong professional league with the presence of the former National Basketball Association players which has helped to boost basketball's popularity (Wood 2010). Confronted with both internal political tensions and a growing instability in the region, the effort of the government has been primarily oriented towards the rebuilding of sports infrastructures destroyed by the war and Israeli bombings and the repositioning of Lebanon in the world's map in staging regional sports competitions such as the Pan Arab Games in 1997, the Asian Cup in 2000 and the Francophone Games in 2009. Beirut, the capital, will host the next edition of the Pan Arab Games in 2015. This endeavour might however be compromised by the political and economic situations and particularly the armed conflict in neighbouring Syria, which is impacting directly on the country. With the amplification of sectarian violence in Syria, Lebanon has now to deal with an unprecedented influx of Syrian refugees and heightened sectarian tensions between Sunni and Shi'a armed groups.

\section{Acknowledgement}

This project could not have been accomplished without the support of the interviewees in Lebanon and Prof Michel Raspaud, 'Sport et Environment Social' Université Joseph Fourrier, Grenoble, France.

\section{Notes}

1. Interview with Adnane Hammoud, director of the Sport and Scout Unit of the Lebanese Ministry of Education, 18 March 2011.

2. Interview done on 26 March 2011 with an employee of the Lebanese Ministry of Education. 3. Interview with Nizar Gharib, President of the office of the training of the managerial staff in the Center of Education, development and research (this institution is under the guardianship of the Lebanese Ministry of Education, 7 April 2011.

4. Interview with Adnane Hammoud, director of the Sport and Scout Unit of the Lebanese Ministry of Education, 18 March 2011.

5. Interview with Andrée Nassour, administrator in the Lebanese Ministry of Youth and Sports, 18 December 2005.

6. Interview with Andrée Nassour, administrator in the Lebanese Ministry of Youth and Sports, 18 December 2005.

7. Interview with Hassan Chararah, advisor of the Lebanese Ministry of Youth and Sport, 18 March 2011.

8. Interview with George Nader, General Secretary of the Lebanese University Sport Federation, 24 March 2011.

9. Interview with Hassan Chararah, advisor of the Lebanese Ministry of Youth and Sport, 18 March 2011.

10. Interview with Adnane Hammoud, director of the Sport and Scout Unit of the Lebanese Ministry of Education, 18 March 2011.

11. Interview with Jihad Salame, candidate for the position of Youth and Sport Minister, 6 October 2011.

12. Interviews conducted with different Lebanese athletes from February to September 2003.

13. Interview with Jihad Salame, candidate for the position of Youth and Sport Minister, 19 November 2013.

14. Interview with Raymond Touma, Financing director of the Lebanese Ministry of Youth and Sports, 18 March 2011.

15. In terms of corruption, in the year 2009, Lebanon occupied the 133rd position among 180 in 
the list of the least corrupted countries by the International Transparency. In 2012, Lebanon occupied the 188th position (The Telegraph, 17 November 2009).

16. Interview with the deputy Simon Abi Ramia, President of the Lebanese Youth and Sports Parliament Committee, 19 February 2010.

17. Interview with Hassan Chararah, advisor of the Lebanese Ministry of Youth and Sport, 18 March 2011.

18. Interview with Jihad Salame, candidate for the position of Youth and Sport Minister, 6 October 2011.

\section{References}

Abi-Habib, M., 12 July 2007. Divided Lebanon debates federalism [online]. Available 7 March 2011 from Ajazeera English: http://english.aljazeera.net/news/ middleeast/2007/06/200852 5184747179802.html [Accessed 15 October 2010].

Blanc, P., 2004. Le sport au Liban: un révélateur de la société. In: Sports et politique en Méditerranée. Les Cahiers de Confluences, December, 159-161. Paris: L'Harmattan. Boukhater,

L., 2004. Basket au Liban. Outre terre, Revue Française de Géopolitique, 8, 129-130. doi:10.3917/oute.008.0129

Gazzeri, H.P. and Isnard, J.F., 2005. The protocol of the cooperation between the French Embassy and the Lebanese Ministry of Youth and Sports for the implementation of coaching programs. Beirut: Lebanese Ministry of Youth and Sports.

Lee, R.D. Jr, Johnson, R.W., and Joyce, P.G., 2008. Public budgeting systems. 8th ed. Sudbury, MA: Jones and Bartlett.

Nassif, N., 2010. Sport policy in Lebanon, 1975 to 2004. Saarbûcken: LAP LAMBERT Academic Publishing.

Nseir, G., 2012. Des communautés et des sports au Liban Enjeux des regroupements sportifs et des rencontres Intercomunautaires. Thesis (PhD). Strasbourg University

Reiche, D., 2011. War minus the shooting? The politics of sport in Lebanon as a unique case in comparative politics. Third world quarterly, 32 (2), 261-277. doi:10.1080/01436597. 2011.560468

Sacre, J., 1990. Report submitted to the Lebanese Government. Beirut: Lebenese Government.

Salibi, K., 1965. The modern history of Lebanon. Worcester: The Trinity Press.

Salibi, K., 1993. A house of many mansions. The history of Lebanon reconsidered. London: IB Tauris \& Co Ltd.

Stanton, A.L., 2012. Pioneer of Olympism in the Middle East: Gabriel Gemayel and Lebanese sport. The international journal of the history of sport, 29 (15), 2115-2130. doi:10.1080/ 09523367.2011.631005

The Telegraph, 17 November 2009. Transparency International's 2009 corruption index: the full ranking of 180 countries [online]. Available from: http://www.telegraph.co.uk/news/newstopics/ mps-expenses/6589735/Transparency-Internationals-2009-corruption-index-the-full-ranking-of180-countries.html [Accessed 13 December 2013]

Wood, J., 2010. Beirut, Lebanon, where former NBA basketball players fulfill hoop dreams, the Christian Science Monitor (6 April). Available from: http://www.csmonitor.com/World/GlobalNews/2010/0406/Beirut-Lebanon-where-former-NBA-basketball-players-fulfill-hoop-dreams 
